\title{
ANALISIS YURIDIS RESOLUSI \\ KONFLIK HUBUNGAN INDUSTRIAL \\ DI KABUPATEN LUWU
}

\author{
Burhanuddin
}

Fakultas Hukum Universitas Andi Jemma Palopo

\begin{abstract}
The settlement of industrial relations case according to Law Number 2 Year 2004 in Luwu Regency is less Effective. The lack of effectiveness of industrial relations dispute settlement cases in Luwu Regency is due to the dependent factors of rights disputes, interest disputes, dismissal disputes and disputes between trade unions/labor unions and independent factors namely the legal structure, legal substance, legal culture and legal awareness. Many Industrial Dispute cases are allowed to take place naturally, without utilizing the legal channels that have been provided in the framework of the Settlement of Industrial Relations Disputes with regard to these social phenomena, there are also factors that support and inhibit the causes of legal smuggling and in the end may lead to cases of Industrial Dispute that are very detrimental to the rights and interests of workers or labor. Social phenomena in question, should not be allowed to be sustainable but must be sought solutions solving for the sake of legal objectives.
\end{abstract}

\section{Keywords:}

Juridical, Conflict Resolution, Industrial Relations

\begin{abstract}
Abstrak
Penyelesaian kasus hubungan industrial menurut Undang-undang Nomor 2 Tahun 2004 di Kabupaten Luwu Kurang Efektif. Kurang efektifnya kasus penyelesaian perselisihan hubungan industrial di Kabupaten Luwu disebabkan faktor dependen yaitu perselisihan hak, perselisihan kepentingan, perselisihan PHK dan perselisihan antar serikat pekerja/serikat buruh serta faktor independen yakni struktur hukum, substansi hukum, kultur hukum dan kesadaran hukum. Banyak kasus-kasus Perselisihan Hubungan Industrial yang dibiarkan berlangsung secara alami (natural), tanpa memanfaatkan saluran hukum yang telah disediakan dalam rangka Penyelesaian Perselisihan Hubungan Industrial Berkenaan dengan fenomena-fenomena sosial tersebut, sekaligus ada yang merupakan faktor pendukung dan penghambat penyebab terjadi penyelundupan hukum dan pada akhirnya dapat menimbulkan kasus-kasus Perselisihan Hubungan
\end{abstract}


Industrial yang sangat merugikan hak dan kepentingan pekerja atau tenaga kerja. Fenomena-fenomena sosial dimaksud, tidak boleh dibiarkan berkelanjutan melainkan harus dicari solusi pemecahannya demi tercapai tujuan hukum.

Kata Kunci:

Yuridis, Resolusi Konflik, Hubungan Industrial

\section{PENDAHULUAN}

\section{A. Latar Belakang}

I

ndonesia merupakan negara hukum (rechtstaat) bukan negara kekuasaan (machstaat) dan bercirikan sebagai negara kesejahteraan modern (welfarestaat), dengan tetap menghormati perbedaan (Bhineka Tunggal Ika) dalam kehidupan berbangsa dan bernegara sebagaimana tertuang di dalam sila-sila Pancasila dasar Filosofi Bangsa Indonesia. Undang-Undang Nomor 13 Tahun 2003 tentang Ketenagakerjaan di dalamnya hanyalah mengatur garis-garis besar dari Hubungan Industrial dan Pemutusan Hubungan kerja, sedang menyangkut teknis pelaksanaan diatur lebih lanjut di dalam berbagai peraturan perundang-undangan sebagai hukum materil ketenagakerjaan.

Secara teoritis apabila terdapat Perselisihan Hak dan Kepentingan maupun Pemutusan Hubungan Kerja sebagai akibat telah terjadi pelanggaran terhadap norma hukum materil ketenagakerjaan, maka secara yuridis formal para pihak tidak diperkenankan melakukan tindakan main hakim sendiri (eigenrichting) yang bernuansa kesewenang-wenangan, melainkan harus ditindak lanjuti melalui penerapan atau penegakan hukum (law enforcement) terhadap norma hukum formil biasa juga disebut hukum acara sebagaimana diatur dalam Undang-Undang Nomor 2 Tahun 2004 tentang Penyelesaian Perselisihan Hubungan Industrial.

Selanjutnya di dalam Undang-Undang Nomor 2 Tahun 2004 telah diatur secara eksplisit tata cara dan prosedur penyelesaian perselisihan Hubungan Industrial, baik melalui peran aktif lembaga Bipatrit agar Perselisihan Hubungan Industrial secara musyawarah untuk mencapai mufakat, Konsiliasi dan Arbitrase maupun gugatmenggugat dengan memberdayakan Badan Peradilan Umum sebagai institusi indipenden yang menyelenggarakan kekuasaan kehakiman sebagaimana dimaksud dalam Undang-undang Nomor 8 Tahun 2004 yang telah merubah dan menyempurnakan Undang-Undang Nomor 2 Tahun 1986 tentang Peradilan Umum.

Kemudian secara empiris masih banyak kasus-kasus Perselisihan Hubungan Industrial yang dibiarkan berlangsung secara alami (natural), tanpa memanfaatkan saluran hukum yang telah disediakan dalam rangka Penyelesaian Perselisihan Hubungan Industrial. Di lain sisi lembaga Bipatrit, Tripatrit dan Administrasi Negara tidak atau kurang pro-aktif memberikan bantuan kepada tenaga kerja yang bersangkutan disebabkan adanya pengaruh dari faktor internal, misalnya tenaga kerja menganggap dirinya sebagai pihak yang lemah atau karena tidak mengetahui 
hak dan kewajiban dalam suatu Hubungan Industrial, sedang pengaruh dari faktor eksternal seperti kedudukan strata sosial dan kekuatan ekonomi pengusaha yang sering dimanfaatkan untuk menekan para tenaga kerja.

Berkenaan dengan fenomena-fenomena sosial tersebut, sekaligus ada yang merupakan faktor pendukung dan penghambat penyebab terjadi penyelundupan hukum dan pada akhirnya dapat menimbulkan kasus-kasus Perselisihan Hubungan Industrial yang sangat merugikan hak dan kepentingan pekerja atau tenaga kerja. Fenomena-fenomena sosial dimaksud, tidak boleh dibiarkan berkelanjutan melainkan harus dicari solusi pemecahannya demi tercapai tujuan hukum (keadilan, kemanfaatan dan kepastian hukum).

Kemudian sebagai salah satu indikasi tidak atau belum terjaminnya hak-hak pekerja pada setiap kasus-kasus Pemutusan Hubungan Kerja, antara lain sebagai berikut:

1. Undang-Undang Nomor 13 Tahun 2003 tidak secara tegas mencantumkan sanksi hukum terhadap pelaksanaan Pasal 156 ayat (2), (3) dan (4) dalam rangka perlindungan pekerja.

2. Substansi Pasal 156 ayat (2) UU Nomor 13 Tahun 2003, tidak tegas mengatur masalah uang pesangon. Hal ini disebabkan substansi hukum yang rumusannya menggunakan kata paling sedikit, sehingga dimungkinkan tidak efektifnya penyelesaian hak pekerja atas risiko Pemutusan Hubungan Kerja.

3. Sebagian besar perusahaan baik dalam bentuk Badan Usaha Milik Negara (BUMN), maupun Badan Usaha Milik Daerah (BUMD), dan perusahaanperusahaan swasta diduga keras belum mempersiapkan cadangan dana Pemutusan Hubungan Kerja ataupun pensiun. Fenomena yang demikian, akan menjadi beban berat apabila terjadi Pemutusan Hubungan Kerja.

4. Kondisi kemampuan perusahaan yang belum siap membayar uang konpensasi atas terjadinya Pemutusan Hubungan Kerja, berdasarkan norma hukum yang diatur dalam berbagai peraturan perundang-undangan, maupun karena minimnya asset perusahaan yang bersangkutan, juga adanya fatwa Mahkamah Agung mengenai pemberian pesangon, dimana perusahaan tidak bisa memutuskan hubungan kerja kalau tidak ada Putusan Pengadilan, jadi kesekian tahun upah harus dibayarkan, hal ini menimbulkan permasalahan bagi perusahaan.

5. Belum adanya sistem atau cara yang lebih efektif dipergunakan untuk menyelesaikan pembayaran hak-hak finansial pekerja yang terkena Pemutusan Hubungan Kerja.

Berkenaan latar belakang kondisi dan fenomena-fenomena sosial di atas, menuntut peran aktif Pemerintah (Pusat dan Daerah) untuk segera mungkin menetapkan kebijaksanaan yang bersifat strategis dalam mencari dan menemukan sistem atau cara yang lebih efektif dan diharapkan dapat menjamin kepastian 
terbayarnya hak-hak finansial pekerja yang terkena kasus Pemutusan Hubungan Kerja.

\section{B. Rumusan Masalah}

Berdasarkan uraian latar belakang masalah di atas, dipandang perlu untuk mengkonkritkan pokok permasalahan dan selanjutnya dituangkan ke dalam rumusan masalah sebagai berikut:

1. Bagaimanakah penyelesaian hubungan industrial menurut Undang-Undang di Kabupaten Luwu?

2. Faktor-faktor apa yang mempengaruhi perselisihan hubungan industrial di Kabupaten Luwu?

\section{Tujuan Penelitian}

1. Tujuan Penelitian:

a. Untuk mengetahui, mengkaji dan menganalisa penyelesaian Perselisihan Hubungan Industrial di Kabupaten Luwu.

b. Untuk mengetahui, mengkaji dan menganalisa kejelasan berkenaan dengan faktor-faktor yang berpengaruh, baik pendukung maupun menghambat pelaksanaan penyelesaian Hubungan Industrial di Kabupaten Luwu.

2. Manfaat Penelitian:

a. Agar supaya dapat ditempuh langkah-langkah hukum dalam rangka berupaya semaksimal pelaksanaan Undang-Undang Nomor 2 Tahun 2004 dalam menyelesaikan kasus Perselisihan Hubungan Industrial.

b. Agara supaya dapat diinventarisasi, diklasifikasi dan diindentivikasi faktor internal dan eksternal, baik yang mendukung maupun yang menghambat pelaksanaan Undang-Undang Nomor 2 Tahun 2004 dalam rangka penyelesaian kasus Perselisihan Industrial di Kabupaten Luwu.

\section{TINJAUAN PUSTAKA}

\section{Pengertian Industrial}

Di dalam Kamus Umum Bahasa Indonesia, kata efektif berasal dari Bahasa Inggris efektive menjadi efektivitas sama dengan keefektivan, mengandung arti keadaan berpengaruh, kemanjuran atau kemujaraban, keberhasilan dan hal mulai berlakunya (Poerwadarminta, 1996 : 266 dan Johan M. Echols, 2001 : 153).

Kemudian mengenai hukum diartikan sebagai hukum positif yang memisahkan antara hukum dan moral, dengan berpijak dari paham dogmatiknormatif kaum positivisme yang cenderung melihat wujud hukum dalam bentuk kaidah belaka (Achmad Ali, 1996:40). Perpaduan pandangan van kan dan Paul Scholten (Achmad Ali, 1996 :42), bahwa hukum adalah keseluruhan aturan hidup yang bersifat memaksa untuk melindungi kepentingan manusia di dalam 
masyarakat, sehingga menjadi suatu petunjuk tentang apa yang layak dilakukan dan apa yang tidak layak untuk dilakukan.

Kemudian oleh Achmad Ali (1998:179) mengemukakan, bahwa topik efektivitas hukum terkait dengan berbagai jawaban yang dibutuhkan terhadap berbagai pertanyaan. Misalnya, faktor-faktor penyebab efektif ataupun tidak efektifnya hukum, benarkan tujuan hukum dapat dibelokkan sehingga berakibat tidak efektifnya hukum tersebut. Benarkan dalam keadaan-keadaan tertentu hukum justru menimbulkan keruwetan baru, bagaimana peran pengkomunikasian hukum untuk mengefektifkan berlakunya.

Menurut Muzni Tambusai (2004:1) mengemukakan, bahwa dalam rangka menuju Hubungan Industrial yang harmonis, dinamis dan berkeadilan, maka timbulnya perselisihan adakalanya sulit dihindari oleh karena kepentingan pengusaha dan pekerja adakalanya tidak selalu selaras.

Dimaksudkan dengan Perselisihan Hubungan Industrial menurut UU Nomor 13 Tahun 2003 pada pasal 1 butir 22, adalah perbedaan pendapat yang mengakibatkan pertentangan antara pengusaha atau gabungan pengusaha dengan pekerja/buruh atau serikat pekerja/serikat buruh karena adanya perselisihan mengenai hak, kepentingan, dan perselisihan pemutusan hubungan kerja serta perselisihan antar serikat pekerja/serikat buruh dalam satu perusahaan (Anonim, 2003: 7).

Perselisihan hubungan industrial dalam pasal 1 butir 22 UU Nomor 13 Tahun 2003 ternyata serupa tapi tak sama (berbeda) dengan rumusan yang tertuang di dalam pasal 1 butir 1 UU Nomor 2 Tahun 2004, bahwa Perselisihan Hubungan Industrial adalah perbedaan pendapat yang mengakibatkan pertentangan antara pengusaha atau gabungan pengusaha dengan pekerja/buruh atau serikat pekerja/serikat buruh karena adanya perselisihan mengenai hak, perselisihan kepentingan (tidak pakai kata dan), perselisihan pemutusan hubungan kerja (tidak menggunakan kata serta, hanya memakai kata dan) perselisihan antar serikat pekerja/serikat buruh dalam satu perusahaan (Anonim, 2004 - I : 3).

\section{Faktor Penyebab Perselisihan Hubungan Industrial}

Setelah diketahui arti dan makna Perselisihan Hubungan Industrial, selanjutnya akan dicari faktor-faktor yang menyebabkan terjadinya Perselisihan Hubungan Industrial dimaksud. Untuk itu perlu diadakan pendekaan terhadap ajaran sebab-akibat (causaliteit), dengan memfokuskan perhatian pada beberapa teori sebagai berikut:

\section{Theory Conditio Sine Qua Non}

Di sebut juga ekuivalensi atau bedingunstheorie diprakarsai Von Buri, bahwa musabab adalah tiap-tiap syarat yang tidak dapat dihilangkan untuk timbulnya 
akibat, karena tiap-tiap syarat adalah sama nilainya dan tidak ada perbedaan antara sebab dan musabab (Moeljatno, 1997: 92).

Di dalam mencari batasan antara syarat dan musabab, terdapat dua pandangan yang saling berhadapan yakni:

a. Batasan secara umum (menggeneralisir), yaitu secara abstrak dan sama sekali tidak terikat suatu perkara tertentu saja, mengambil pendirian sebelum timbul akibat (ante faktum), dalam perkembangan ilmu hukum disebut teori menggeneralisir.

b. Batasan secara khusus (mengindividualisir) tidak meninjau secara abstrak dan umum, tetapi secara konkrit mengenai perkara tertentu saja. Kini berpendirian, tiap-tiap kejadian ditinjau sendiri-sendiri menentukan musabab dari akibat, disebut teori mengindividualisir.

\section{Theory Adequat}

Teori menggeneralisir dikenal dengan teori adequat disponsori J. von Kries, bahwa musabab dari suatu kejadian adalah syarat pada umumnya menurut jalan kejadian yang normal, dapat atau mampu menimbulkan akibat atau kejadian tersebut (Moejatno, 1997: 96-99).

Perselisihan Hubungan Industrial menurut pasal 2 Undang-Undang Nomor 2 Tahun 2004, dapat diklasifikasi atas 4 (empat) jenis perselisihan yakni:

1. Perselisihan hak

2. Perselisihan kepentingan

3. Perselisihan pemutusan hubungan kerja

4. Perselisihan antar serikat pekerja/serikat buruh.

Perselisihan Hubungan Industrial yang dikategorikan sebagai perselisihan hak hanya tertuju pada hak normatif saja, terjadi karena adanya perbedaan pendapat yang menyebabkan pertentangan yang timbul karena tidak dipenuhinya hak. Akibat adanya perbedaan pelaksanaan atau penafsiran terhadap peraturan perundangundangan, perjanjian kerja, peraturan perusahaan ataupun terhadap perjanjian kerja bersama.

Hak normatif sebagai obyek Perselisihan Hubungan Industrial, menurut Penjelasan pasal 2 huruf a Undang-undang Nomor 2 Tahun 2004, yakni perselisihan mengenai hak normatif yang sudah ditetapkan dalam perjanjian kerja, peraturan perusahaan, perjanjian kerja bersama atau peraturan perundang-undangan. Sedangkan pada pasal 118 Undang-Undang Nomor 13 Tahun 2003, ditegaskan bahwa dalam 1 (satu) perusahaan hanya dapat dibuat 1 (satu) perjanjian kerja bersama yang berlaku bagi seluruh pekerja/buruh di perusahaan.

Rumusan pada Pasal 118 UU Nomor 13 Tahun 2003, berpotensi terjadinya perselisihan antar Serikat Pekerja/Serikat Buruh. Terutama apabila di dalam suatu perusahaan terdapat lebih dari satu organisasi Serikat Pekerja/Serikat Buruh, tidak mungkin serikat Pekerja/Serikat Buruh yang tidak ikut dalam Perjanjian Bersama 
secara serta merta akan ikut dan tunduk pada isi Perjanjian Bersama yang kemungkinan akan sangat merugikan kepentingan organisasi dan atau anggotanya.

Hak menurut van Apeldoorn (1983: 68-86), diasumsikan sebagai hukum dan hukum sendiri dipandang sebagai kekuasaan. Kemudian oleh Satjipto Rahardjo (1996 :93), bahwa hak merupakan pengalokasian kekuasaan yang dilakukan secara terukur dalam arti ditentukan keluasaan dan kedalamannya. Selanjutnya oleh Soerjono Soekanto (1993: 7-8), bahwa hak merupakan suatu wewenang untuk berbuat atau tidak berbuat, sedang kewajiban merupakan tugas yang dibebankan.

\section{Penyelesaian Perselisihan Hubungan Industrial}

Setelah diketahui faktor penyebab dan klasifikasi jenis perselisihan Hubungan Industrial, selanjutnya akan dijelaskan proses penyelesaian dari setiap jenis Perselisihan Hubungan Industrial. Salah satu hal penting yang patut diingat dalam Perselisihan Hubungan Industrial, bahwa setiap bentuk tindakan main hakim sendiri (eigenrichting) merupakan perbuatan melanggar hukum. Sedang perbuatan melawan hukum itu sendiri, sangat tidak diharapkan terjadinya dalam suatu negara hukum seperti Indonesia.

Tindakan menghakimi sendiri (eigenrichting) merupakan tindakan untuk melaksanakan hak menurut kehendaknya sendiri yang bersifat sewenang-wenang, tanpa persetujuan dari pihak lain yang berkepentingan, sehingga akan menimbulkan kerugian (Sudikno Mertokusumo, 1999: 2).

Kemudian tinggi atau rendahnya kadar kepercayaan warga masyarakat terhadap pranata Pengadilan, juga berpengaruh terhadap tinggi rendahnya kadar tindakan main hakim sendiri (eigenrichting) di kalangan masyarakat. Semakin tinggi kepercayaan warga masyarakat terhadap pranata Pengadilan, maka semakin rendah kadar tindakan main hakim sendiri di dalam masyarakat itu. Sebaliknya semakin rendah tingkat kepercayaan warga masyarakat terhadap pranata Pengadilan, maka akan semakin tinggi kadar tindakan main hakim sendiri dalam masyarakat yang bersangkutan (Achmad Ali, 1999: 8).

Sehubungan dengan tidak dibenarkannya tindakan main hakim sendiri dalam rangka penyelesaian Perselisihan Hubungan Industrial menurut sistem hukum yang berlaku di Indonesia, sehingga Undang-Undang Nomor 2 tahun 2004 membuka 2 (dua) saluran hukum secara bersamaan guna dapat dipergunakan untuk menyelesaikan setiap Perselisihan Hubungan Industrial yakni melalui saluran litigasi dan non litigasi. Masyarakat Amerika Serikat cenderung menggunakan saluran litigasi, sedangkan masyarakat Korea dan Jepang cenderung menggunakan saluran non litigasi.

Berkenaan dengan petunjuk penyelesaian Perselisihan Hubungan Industrial sebagaimana diatur di dalam pasal 3, 4 dan 5 UU Nomor 2 Tahun 2004, dapatlah diketahui bahwa Pembuat Undang-Undang telah menetapkan adanya tahapan- 
tahapan yang harus dilalui dalam rangka proses penyelesaian Perselisihan Hubungan Industrial, yakni:

1. Tahap musyawarah untuk mencapai mufakat

2. Tahap intervensi administrasi negara

3. Tahap kebebasan memilih alternatif penyelesaian perselisihan

4. Tahap gugat-menggugat melalui Pengadilan Hubungan Industrial.

Penyelesaian perselisihan Hubungan industrial pada tahap pertama diperankan oleh lembaga kerja sama Bipatrit sebagai forum komunikasi dan konsultasi mengenai hal-hal yang berkaitan dengan hubungan industrial di satu perusahaan yang anggotanya terdiri dari pengusaha dan serikat pekerja/serikat buruh yang sudah tercatat pada instansi yang bertanggung jawab di bidang ketenagakerjaan atau unsur pekerja/buruh.

Persoalannya apabila perundingan secara musyawarah yang dimotori oleh lembaga kerja sama Bipatrit gagal mencapai mufakat sebagaimana dimaksud pasal 3 ayat (3) UU Nomor 2 Tahun 2004, maka barulah beralih pada penyelesaian tahap kedua dengan cara memberikan kesempatan administrasi negara (instansi setempat yang bertanggung jawab di bidang ketenagakerjaan) untuk ikut campur memediasi penyelesaian perselisihan hubungan industrial.

Ikut campur tangannya administrasi negara dalam berupaya menyelesaikan perselisihan hubungan industrial, merupakan salah satu wujud eksistensi Indonesia sebagai suatu bentuk negara kesejahteraah modern (welfarestaate). Hanya saja keterlibatannya relatif sangat terbatas pada penetapan pilihan alternatif dari para pihak yang berselisih dalam rangka penyelesaian perselisihan hubungan industrial melalui mediator, baik secara Konsiliasi maupun dengan cara Arbitrase sebagaimana dimaksu dalam pasal 5 Undang-Undang Nomor 2 Tahun 2004.

Apabila Mediator (Konsiliator dan arbiter) ternyata juga gagal menyelesaikan perselisihan Hubungan Industrial, maka untuk tercapainya tujuan hukum (keadilan, Kemanfaatan dan kepastian hukum) barulah ditingkatkan pada tahap gugatmenggugat melalui Pengadilan Hubungan Industrial yang ada dalam lingkungan Peradilan Umum (Pengadilan Negeri, Pengadilan Tinggi dan Mahkamah Agung).

\section{Lembaga Penyelesaian Perselisihan Hubungan Industrial}

Di dalam pasal 136 ayat (2) Undang-Undang Nomor 13 tahun 2003, ditegaskan bahwa dalam hal penyelesaian secara musyawarah untuk mufakat sebagaimana dimaksud dalam ayat (1) tidak tercapai, maka pengusaha dan pekerja/buruh atau serikat pekerja/serikat buruh menyelesaikan perselisihan hubungan industrial melalui prosedur penyelesaian perselisihan hubungan industrial yang diatur dengan undang-undang.

Undang-undang yang dimaksud tersebut, yakni undang-undang Nomor 2 tahun 2004 di dalamnya diatur hukum acara yang beriorientasi pada tata cara dan 
prosedur penyelesaian kasus-kasus perselisihan hubungan industrial secara non litigasi (Bab II mulai pasal 6 sampai dengan pasal 54), maupun secara litigasi (Bab III mulai pasal 55 sampai dengan pasal 80; dan Bab IV mulai pasal 81 sampai dengan pasal 115).

Dengan demikian, maka pembuat undang-undang telah menyediakan 2 (dua) lembaga yang berwenang menangani penyelesaian perselisihan hubungan industrial di Indonesia, yakni lembaga non litigasi dan lembaga litigasi.

1. Lembaga Non Litigasi

Penyelesaian perselisihan hubungan industrial melalui lembaga non litigasi, diklasifikasi atas:

a. Penyelesaian melalui Bipatrit

Tata cara dan prosedur penyelesaian melalui Bipatrit diatur dalam pasal 6 dan 7 Undang-Undang Nomor 2 Tahun 2004. Hasil kerja dibuatkan risalah yang ditanda tangani oleh para pihak, dalam risalah tersebut berisi:

1). Nama lengkap dan alamat para pihak.

2). Tanggal dan tempat perundingan

3). Pokok masalah atau alasan perselisihan.

4). Pendapat para pihak

5). Kesimpulan atau hasil perundingan

6). Tanggal serta tanda tangan para pihak yang melakukan perundingan.

Apabila dalam musyawarah berhasil mencapai mufakat, lalu dibuatkan perjanjian bersama dan perjanjiannya wajib didaftarkan pada Pengadilan Hubungan Industrial. Oleh pengadilan diberikan bukti pendaftaran sebagai bagian integral dari perjanjian bersama. Jika salah satu pihak tidak melaksanakan perjanjian bersama, maka pihak yang dirugikan dapat mengajukan permohonan pelaksanaan eksekusi pada Pengadilan Hubungan Industrial.

Permohonan pelaksanaan eksekusi bagi pemohon yang tidak berdomisili di tempat kedudukan Pengadilan Hubungan Industrial yang telah mendaftarkan perjanjian bersama tersebut, maka untuk kepentingan hukum permohonan eksekusinya dapat diajukan melalui Pengadilan Hubungan Industrial di tempat domisili pemohon. Permohonan pelaksanaan eksekusi tersebut, selanjutnya akan diteruskan kepada Pengadilan Hubungan Industrial yang berwenang melaksanakan eksekusi yang dimohonkan.

b. Penyelesaian melalui Mediasi

Tata cara dan prosedur penyelesaian perselisihan melalui mediasi dilakukan oleh Mediator, diatur lebih lanjut dalam pasal 8 sampai dengan pasal 16 UndangUndang Nomor 2 Tahun 2004. Mediator dimaksud berada pada setiap kantor instansi yang bertanggung jawab di bidang ketenagakerjaan kabupaten/kota dengan ketentuan sebagai berikut: 
1). Mengadakan penelitian mengenai duduk perkara dan menyidangkan, serta menyelesaikan tugasnya selama 30 (tiga puluh) hari kerja.

2). Memanggil saksi dan ahli guna diminta/didengar keterangannya, membukakan buku dan memperlihatkan surat yang diperlukan.

3). Wajib menjaga kerahasiaan keterangan dari para pihak yang terkait dengan perselisihan hubungan industrial.

4). Apabila tercapai kesepakatan, dibuatkan perjanjian bersama dan perjanjian bersama didaftarkan pada Pengadilan Hubungan Industrial.

5). Apabila tidak tercapai kesepakatan, maka:

a. Mediator mengeluarkan anjuran tertulis dan selambat-lambatnya 10 (sepuluh) hari sudah ada pada para pihak.

b. Para pihak memberikan jawaban selambat-lambatnya 10 (sepuluh) hari isinya menyetujui atau menolak, sekaligus memberikan pendapatnya.

c. Apabila menyetujui lalu dibuatkan perjanjian bersama untuk didaftarkan pada Pengadilan Hubungan Industrial.

c. Penyelesaian melalui Konsiliasi

Tata cara dan prosedur penyelesaian perselisihan melalui Konsiliasi oleh Konsiliator, diatur dalam pasal 17 sampai dengan pasal 28 Undang-Undang Nomor 2 Tahun 2004. Konsiliator yang berwenang menangani kasus perselisihan hubungan industrial, adalah mereka yang telah terdaftar pada kantor instansi yang bertanggung jawab di bidang ketenagakerjaan kabupaten/kota dengan tiga jenis perselisihan, sebagai berikut:

1) Perselisihan kepentingan

2) Perselisihan pemutusan hubungan kerja.

3) Perselisihan antar serikat pekerja/serikat buruh.

Konsiliator yang telah menerima permintaan penyelesaian perselisihan hubungan industrial mengambil langkah-langkah, sebagai berikut:

1) Meneliti duduk perkara dan menyidangkan, serta menyelesaikan tugasnya selama 30 (tiga puluh) hari kerja.

2) Memanggil saksi dan ahli guna diminta/didengar keterangannya, membukakan buku dan memperlihatkan surat yang diperlukan.

3) Wajib menjaga kerahasiaan keterangan.

4) Apabila tercapai kesepakatan, dibuatkan perjanjian bersama dan didaftarkan pada Pengadilan Hubungan Industrial.

5) Dalam hal anjuran tertulis ditolak, maka perselisihannya dapat dilanjutkan melalui gugat-menggugat ke Pengadilan Hubungan Industrial pada Pengadilan Negeri setempat.

6) Apabila tidak tercapai kesepakatan, maka:

a. Konsiliator mengeluarkan anjuran tertulis dan selambat-lambatnya 10 (sepuluh) hari sudah ada pada pihak. 
b. Para pihak memberikan jawaban selambat-lambatnya 10 (sepuluh) hari isinya menyetujui atau menolak, sekaligus memberikan pendapatnya.

c. Apabila menyetujui lalu dibuatkan perjanjian bersama untuk didaftarkan pada Pengadilan Hubungan Industrial.

d. Penyelesaian melalui Arbitrase

Penyelesaian melalui arbitrase didasarkan atas kesepakatan para pihak yang berselisih, kesepakatan dimaksud dibuat secara tertulis dalam bentuk surat perjanjian arbitrase. Arbiter berwenang menyelesaikan perselisihan kepentingan dan perselisihan antar serikat pekerja/serikat buruh dalam satu perusahaan dalam wilayah Republik Indonesia selambat-lambatnya 30 (tiga puluh) hari kerja dan dapat diperpanjang satu kali selama 14 (empat belas) hari kerja, sebagaimana diatur dalam pasal 29 sampai dengan pasal 54 UU Nomor 2 Tahun 2004.

Apabila dalam sidang pertama atau sidang kedua, secara nyata pengusaha terbukti tidak melaksanakan kewajibannya sebagaimana dimaksud pasal 155 ayat (3) Undang-Undang Nomor 13 tahun 2004, maka Majelis Hakim dapat menjatuhkan putusan sela berupa perintah kepada pengusaha untuk membayar upah berserta hak-hak lainnya yang biasa diterima pekerja/buruh yang bersangkutan.

Sekiranya pengusaha tidak melaksanakan putusan sela, maka Majelis Hakim dapat memerintahkan sita jaminan dalam suatu penetapan hakim. Terhadap putusan sela dan penetapan sita jaminan, tidak dapat diajukan perlawanan dan/atau tidak dapat digunakan upaya hukum.

Kemudian di dalam putusan Pengadilan Hubungan Industrial, ditetapkan kewajiban yang harus dilakukan dan/atau hak yang harus diterima oleh para pihak atau salah satu pihak atas setiap perselisihan hubungan industrial.

e. Pemeriksaan dengan acara cepat

Permohonan untuk menggunakan pemeriksaan dengan acara cepat dapat diajukan oleh para pihak atau salah satu pihak yang berselisih, disertai alasan-alasan hukum yang cukup mendesak harus dapat disimpulkan dari permohonan pihak yang berkepentingan. Dalam jangka 7 (tujuh) hari kerja, Ketua Pengadilan Negeri, mengeluarkan penetapan tentang dikabulkan atau tidak dikabulkannya permohonan penggunaan pemeriksaan dengan acara cepat.

Apabila permohonan ditolak oleh Ketua Pengadilan Negeri, maka yang dipergunakan adalah pemeriksaan dengan acara biasa. Lain halnya kalau permohonan dikabulkan, maka yang dipergunakan adalah pemeriksaan dengan acara cepat. Pemeriksaan dengan acara cepat, berarti dalam tenggang waktu paling lama 14 (empat belas) hari kerja perselisihan hubungan industrial sudah harus diputuskan.

f. Pengambilan Putusan

Majelis Hakim pada Pengadilan Hubungan Industrial di dalam pengambilan keputusan berwajiban untuk mempertimbangkan norma hukum, baik yang termuat 
di dalam perjanjian kerja yang ada, kebiasaan dan keadilan. Majelis hakim akan memberikan putusannya. Putusan hakim diberikan selambat-lambatnya 50 (lima puluh) hari kerja, terhitung sejak hari sidang pertama.

Majelis hakim dapat mengeluarkan putusan yang dapat dilaksanakan lebih dahulu, walaupun putusan tersebut terbuka kemungkinan untuk diajukan perlawanan atau kasasi pada Mahkamah Agung.

Di samping itu, putusan hakim harus dibacakan dalam sidang yang terbuka untuk umum. Tidak dipenuhinya ketentuan tersebut, berakibat putusan pengadilan tidak sah dan tidak mempunyai kekuatan hukum sehingga tidak dapat dilaksanakan atau dieksekusi.

g. Pelaksanaan Eksekusi Perselisihan Hubungan Industrial

Sebagaimana telah dikemukakan pada bagian terdahulu, bahwa penyelesaian perselisihan hubungan industrial melalui sistem litigasi menggunakan hukum acara perdata. Kemudian di dalam hukum acara perdata itu sendiri ditetapkan, bahwa suatu perkara perdata diajukan oleh pihak yang bersangkutan kepada badan peradilan untuk mendapatkan pemecahan atau penyelesaian yang dimulai dari tahap pemeriksaan dan disudahi dengan dijatuhkannya putusan pengadilan. Namun demikian, putusan pengadilan tidak ada artinya, kalau putusan tersebut tidak dapat dilaksanakan.

Suatu putusan hakim yang telah memperoleh kekuatan hukum yang pasti dapat dilaksanakan secara suka rela oleh yang bersangkutan atau pihak yang dilakukan, akan tetapi sering terjadi pihak yang dikalahkan tidak bersedia melaksanakan putusan hakim secara suka rela, sehingga diperlukan bantuan pengadilan untuk melaksanakan putusan tersebut (Sudikno Mertokusumo, 1992: 205-206).

\section{METODE PENELITIAN}

\section{A. Lokasi Penelitian}

Penelitian penyelesaian perselisihan hubungan industrial akan dilaksanakan dalam wilayah Kabupaten Luwu, Kantor Organisasi Serikat Pekerja, Kantor Perusahaan yang menjalin hubungan industrial, Kantor Advokat/Pengacara dan di tempat kediaman tenaga kerja yang sedang dan/atau telah mengalami perselisihan hubungan industrial.

\section{B. Jenis dan Sumber Data}

Penelitian ini berupaya semaksimal mungkin menghimpun dua jenis data dari sumber data yang berlainan, sebagai berikut:

1. Data Primer atau data bersifat empiris yang mempunyai nilai praktis, karena bersumber dari pengetahuan dan pengalaman responden yang diperoleh secara langsung pemanfaatan metode-metode tertentu dan sistematik baik melalui pengisian kuisioner atau daftar pertanyaan maupun wawancara dan observasi. 
2. Data Sekunder atau data bersifat teoritas, oleh karena bersumber dari bahan bacaan atau literatur dan dokumentasi, termasuk berkas perkara perselisihan hubungan industrial, serta berbagai peraturan perundang-undangan yang erat relevansinya dengan obyek yang diteliti.

\section{Teknik Pengumpulan Data}

Agar supaya akuratisasi penelitian ini memperoleh data primer dan sekunder sesuai dengan rencana yang telah tersusun secara sistematis, maka secara ex offcio penelitian ini akan mempergunakan teknik pengumpulan data sebagai berikut:

1. Penelitian lapang, yakni suatu teknik pengumpulan data primer dengan cara melakukan kunjungan langsung di lokasi penelitian guna dapat mengadakan observasi atau pengamatan, wawancara, interviu, tanya jawab serta diskusi.

2. Penelitian kepustakaan, yakni suatu teknik pengumpulan data sekunder dengan cara membaca buku literatur, karya ilmiah, brosur, dokumentasi dan berbagai peraturan perundang-undangan yang erat relevansinya dengan upaya hukum penyelesaian perselisihan hubungan industrial.

\section{HASIL PENELITIAN DAN PEMBAHASAN}

\section{A. Analisis Yuridis Pelaksanaan Resolusi Konflik di Kab. Luwu}

Berbagai usaha dan upaya telah dilakukan pemerintah di Kabupaten Luwu, dalam rangka mengantisipasi segala kemungkinan terjadinya perselisihan hubungan industrial, seperti mengadakan pertemuan secara berkala dengan para pengusaha dan serikat pengusaha, pekerja dan serikat pekerja/buruh. Namun usaha dan upaya positif dimaksud, belum berhasil meniadakan fenomena-fenomena sosial yang dapat menghindari terjadinya benturan di antara pekerja dan pengusaha. Akan tetapi terhadap fenomena-fenomena sosial dimaksud, justru menjadi pemicu dan penyebab terjadinya perselisihan hubungan industrial.

Perselisihan hubungan industrial yang terjadi di Kabupaten Luwu, tidak hanya menimpa perusahaan-perusahaan yang memperkerjakan tenaga kerja dalam jumlah dan skala besar, akan tetapi dapat pula merambah pada perusahaan-perusahaan yang tergolong menengah dan kecil.

Adapun kasus-kasus perselisihan hubungan industrial yang terjadi selama kurun waktu lima tahun terkahir di Kabupaten Luwu, diklasifikasi secara terinci dalam tabel berikut ini.

\section{Tabel 1}

Kasus Perselisihan Hubungan Industrial di Kabupaten Luwu Tahun 2014 sampai dengan Tahun 2016

\begin{tabular}{|c|c|c|c|c|}
\hline No. & Tahun & Banyaknya kasus & Persentase & Keterangan \\
\hline 1 & 2014 & 6 & 24 & \\
2 & 2015 & 9 & 49 & \\
3 & 2016 & 5 & 27 & \\
\hline
\end{tabular}




\begin{tabular}{|l|l|l|l|l|}
\hline & Jumlah & 20 & 100 & \\
\hline
\end{tabular}

Sumber data: Dinas Tenaga Kerja Kabupaten Luwu

Terjadinya penurunan angka perselisihan hubungan industrial selama kurun waktu dari tahun 2014 sampai dengan tahun 2016 di Kabupaten Luwu disebabkan beberapa faktor sebagai berikut:

1. Semakin diaktifkannya penyuluhan hukum dan sosialisasi peraturan perundang-undangan berkenaan dengan hubungan industrial oleh Kantor Dinas Tenaga Kerja Kabupaten Luwu.

2. Semakin diberdayakannya pengawasan dan pembinaan ketenagakerjaan oleh Kantor Dinas Tenaga Kerja Kabupaten Luwu.

3. Adanya saling pengertian antara pekerja, serikat pekerja/buruh, pengusaha dan serikat pengusaha.

Kantor Dinas Tenaga Kerja Kabupaten Luwu, telah memprogramkan untuk melaksanakan pengawasan dan pembinaan, serta penyuluhan hukum dan sosialisasi terhadap berbagai peraturan perundang-undangan ketenagakerjaan pada setiap triwulan. Dana penyuluhan hukum dan sosialisasi peraturan perundang-undangan ketenagakerjaan, keseluruhannya dianggarkan bersumber dari Anggaran Pendapatan dan Belanja Pemerintah Kabupaten Luwu.

Di samping itu, Kantor Dinas Tenaga Kerja Kabupaten Luwu tetap berupaya semaksimal mungkin untuk menjalin hubungan kerja sama dengan para pengusaha dan serikat pengusaha, maupun terhadap pekerja dan beberapa organisasi serikat pekerja/buruh. Hubungan kerja sam dimaksud, lebih berorientasi pada peningkatan kinerja dan produktivitas hasil kerja sebagaimana diamanahkan Undang-Undang Nomor 13 Tahun 2003 Juncto Undang-Undang Nomor 2 Tahun 2004.

Penyelesaian perbedaan penafsiran tentang hak-hak normatif pekerja melalui forum musyawarah untuk mufakat dilaksanakan oleh lembaga bipatrit, sebagai langkah awal atau tahap pertama dari suatu penyelesaian perselisihan hubungan industrial. Kasus-kasus perselisihan hubungan industrial yang berhasil ditangani dan diselesaikan oleh lembaga bipatrit, adalah kasus-kasus yang sifatnya tidak terlalu signifikan.

Perbedaan penafsiran terhadap hak-hak normatif pekerja dimaksud, sehingga menjadi perselisihan hubungan industrial. Perselisihan ini tidak berhasil (gagal) diselesaikan secara langsung atau suka rela oleh lembaga Bipatrit, sehingga ditingkatkan penyelesaiannya pada Kantor Dinas Tenaga Kerja Kabupaten Luwu melalui lembaga mediasi, arbitrase dan konsiliasi. Namun hasilnyapun dianggap gagal sehingga atas rekomendasi pasal 5 UU Nomor 2 Tahun 2004, diselesaikan melalui bantuan badan peradilan yang dalam hal ini dilaksanakan dan diselesaikan oleh pengadilan hubungan industrial. 


\section{B. Penyelesaian Kasus Hubungan Industrial}

Sebagaimana telah dikemukakan pada bagian terdahulu, bahwa Negara Republik Indonesia adalah negara hukum maka secara ex officio tindakan main hakim sendiri yang didasarkan atas kesewenang-wenangan merupakan perbuatan yang bertentangan dengan hukum. Untuk mengantisipasi tindakan main hakim sendiri, pemerintah membentuk beberapa lembaga pelaksana dan penegak hukum yang diharapkan dapat membantu pencari keadilan, terutama bagi pekerja yang merasa dirugikan akibat dari tindakan pengusaha.

Berkenaan dengan hal tersebut, maka sistem hukum yang berlaku di Indonesia, secara tegas tidak dibenarkannya tindakan main hakim sendiri (eigenrichting). Tidak adanya alasan pembenar bagi tindakan main hakim sendiri, karena eksistensi Eigenrichting tergolong perbuatan melanggar hukum.

Sistem hukum yang berlaku di Indonesia, bahwa setiap terjadi perbedaan penafsiran menyebabkan terjadinya perselisihan hubungan industrial, maka penyelesaiannya harus melalui tata cara dan prosedur yang diatur secara limitatif dalam pasal 3, 4 dan 5 UU Nomor 2 tahun 2004.

Sehubungan dengan hal tersebut, maka adanya larangan eigenrichting dan norma hukum yang diatur dalam pasal 3, 4 dan 5 UU Nomor 2 Tahun 2004, sehingga selama kurun waktu dari tahun 2004 sampai dengan tahun 2008 tercatat sebanyak 689 kasus (100 \%) hubungan industrial di Kabupaten Luwu. Keseluruhan perselisihan hubungan industrial diselesaikan melalui pemberdayaan lembaga Bipatrit, Konsiliasi, Arbitrase, Mediator dan pengadilan Hubungan Industrial.

Masih tingginya minat masyarakat yang terlibat langsung kasus perselisihan hubungan industrial menggunakan lembaga litigasi menyelesaikan permasalahan hukumnya, disebabkan keterlibatan pihak ketiga (hakim karier) yang dianggap lebih independen dan sama sekali tidak mempunyai kepentingan dalam menyelesaikan setiap kasus perselisihan hubungan industrial. Lain halnya dengan penggunaan lembaga non litigasi, seperti Bipatrit, Konsiliasi, Arbitrase dan Mediator masih melibatkan salah satu unsur dari para pihak yang berselisih, sehingga keputusannya pun dianggap tidak atau belum adil.

Adapun latar belakang pribadi responden yang menyatakan efektif penggunaan lembaga litigasi menyelesaikan perselisihan hubungan industrial berasal dari unsur sebagian pegawai dari Kantor Dinas Tenaga Kerja Kabupaten Luwu, sebagian pengusaha, keseluruhan pengurus organisasi serikat kerja/buruk, dan advokat serta pekerja yang pernah dan sedang mengalami perselisihan hubungan industrial.

Kemudian latar belakang pribadi responden yang menyatakan kurang efektif dan/atau tidak efektif penggunaan lembaga litigasi menyelesaikan perselisihan hubungan industrial, adalah mereka yang sebagian berasal dari kalangan pegawai Kantor Dinas Tenaga Kerja Kabupaten Luwu, terutama bagi mereka yang membidangi masalah-masalah perselisihan hubungan industrial, serta sebagian dari 
kalangan pengusaha yang pernah dinyatakan kalah melalui putusan pengadilan hubungan industrial.

Pandangan responden yang menolak pemberdayaan lembaga litigasi sebagai institusi yang berhak menyelesaikan kasus-kasus perselisihan hubungan industrial, ternyata bersesuaian dengan pemberitaan media Kompas pada rubrik Bisnis dan Keuangan yang pengadilan hubungan industrial membutuhkan sistem baru agar dapat lebih efektif menangani sengketa perburuhan. Walaupun ada beberapa kelemahan pengadilan hubungan industrial sebagai lembaga litigasi yang dikemukakan oleh kedua responden sebagai alasan penolakan keberadaan lembaga litigasi dimaksud, namun keduanya secara jujur dan transparan mengakui bahwa keputusan pengadilan hubungan industrial jauh lebih adil daripada keputusan lembaga non litigasi.

\section{Faktor Yang Mempengaruhi Penyelesaian Kasus Hubungan Industrial}

Sebagaimana telah dikemukakan pada bagian terdahulu, bahwa pelaksanaan norma dan kaidah hukum yang diatur dalam peraturan perundang-undangan tidaklah semudah membalikkan kedua telapak tangan. Norma dan kaidah hukum yang diatur dalam peraturan perundang-undangan, karena sebaik dan serapi manapun untaian kata menjadi kalimat hukum sering menimbulkan perbedaan penafsiran di antara para pihak yang berkepentingan. Apabila terhadap suatu norma dan kaidah hukum menimbulkan penafsiran yang berbeda di antara para pihak yang berkepentingan, maka secara ex officio akan menjadi akar masalah timbulnya perselisihan.

Demikian pula halnya dengan peraturan perundang-undangan yang mengatur ketenagakerjaan atau hubungan industrial, apabila analisis dari teori-teori konflik yang bermuara pada sebab-akibat (causaliteit) khususnya Theory Conditio Sine Qua Non (von buri), maka terjadinya ketidakseimbangan dalam pelaksanaan hubungan industrial dapat mempengaruhi keadaan kondusif di antara pekerja atau serikat kerja/buruh dengan perusahaan atau serikat pengusaha. Keadaan yang tidak kondusif dimaksud, dapat mempengaruhi produktivitas kerja dan produktivitas usaha sehingga diperlukan tindakan dan kebijakan yang dapat menetralisir suasana. Namun tindakan dan kebijakan tersebut, justru menjadi salah satu faktor dependen (terikat) penyebab terjadinya kasus-kasus perselisihan hak, perselisihan kepentingan, perselisihan pemutusan hubungan kerja, maupun perselisihan antar serikat pekerja/buruh.

Di samping faktor-faktor dependen tersebut, ternyata konflik yang terjadi dalam hubungan industrial dapat pula disebabkan karena besarnya pengaruh dari faktor-faktor independen (bebas) yang indikatornya terdiri dari struktur hukum, substansi hukum, kultur hukum dan tingkat kesadaran hukum dari masing-masing pihak yang berkepentingan. 


\section{KESIMPULAN DAN SARAN}

\section{A. Kesimpulan}

Berdasarkan uraian dan pembahasan, kajian dan analisis pada bab terdahulu, maka pada bagian ini dapatlah ditarik beberapa kesimpulan sekaligus menjadi jawaban dari pokok masalah yang termuat dalam rumusan masalah sebagai berikut:

1. Penyelesaian kasus hubungan industrial menurut Undang-undang Nomor 2 Tahun 2004 di Kabupaten Luwu Kurang Efektif.

2. Kurang efektifnya kasus penyelesaian perselisihan hubungan industrial di Kabupaten Luwu disebabkan faktor dependen yaitu perselisihan hak, perselisihan kepentingan, perselisihan PHK dan perselisihan antar serikat pekerja/serikat buruh serta faktor independen yakni struktur hukum, substansi hukum, kultur hukum dan kesadaran hukum.

\section{B. Saran - Saran}

Sehubungan dengan beberapa kesimpulan di atas, selanjutnya diajukan saran yang dapat dipertimbangkan dalam rangka pembinaan hukum perburuhan atau hubungan industrial di Indonesia, sebagai berikut:

1. Pemerintah perlu meninjau kembali undang-undang Nomor 13 tahun 2003 untuk diadakan perbaikan dan penyempurnaan. Sekaligus mensinerjikan dengan norma hukum yang diatur dalam Undang-Undang Nomor 2 Tahun 2004. Kemudian norma hukum yang diatur di dalamnya tidak menimbulkan penafsiran hukum yang dapat menjadi biang keladi terjadinya perselisihan hubungan industrial.

2. Pemerintah perlu lebih meningkatkan pelaksanaan pengawasan hubungan industrial, terutama pengawasan terhadap norma hukum yang diatur dalam peraturan perusahaan, perjanjian kerja maupun terhadap perjanjian kerja bersama.

\section{Daftar Pustaka}

Abdulkadir Muhammad, 1996. Hukum Acara Perdata Indonesia. Bandung, Alumni. Achmad Ali, 1996. Menguak Tabir Hukum (Suatu Kajian Filosofis dan Sosiologis). Jakarta, Candra Parata. 1998. Menjelajahi Kajian Empiris terhadap Hukum. Jakarta, Watampone. 1999. Peranan Pengadilan Sebagai Pranata Sosial; Suatu Tinjauan Sosiologi Hukum (Pidato Pengukuhan Guru Besar Tetap Ilmu Hukum UNHAS). Makassar, Universitas Hasanuddin. 
Anonim, 2003. Undang-Undang Nomor 13 Tahun 2003 tentang Ketenagakerjaan. Jakarta, departemen Tenaga kerja dan Transmigrasi Republik Indonesia.

2004 - I. Undang-Undang Republik Indonesia Nomor 2 Tahun 2004 tentang Penyelesaian Perselisihan Hubungan Industrial. Jakarta, Asosiasi Hubungan Industrial Indonesia.

2004 - II. Himpunan Peraturan Perundang-Undangan; Pembentukan Peraturan Perundang-undangan; Undang-Undang Nomor 10 tahun 2004. Bandung, Fokus media.

Djazuli Bachar, 1997. Eksekusi Putusan Perkara Perdata; segi hukum dan penegakan Hukum. Jakarta, Akademika Presindo.

Johan M. Echols dan Hassan Shadly, 2001. Kamus Inggris Indonesia. Jakarta. Gramedia.

Kansil, C.S.T dan Christine S.T. Kansil dan Engeline R. Palandeng, 2001. Konstitusikonstitusi Indonesia tahun 1945-2000. Jakarta, Pustaka Sinar harapan.

Kartasapoetra, G dan Rience G. Widianingsih, 1992. Pokok-pokok Hukum Perburuhan. Bandung, Armic.

Kuffal, H.M.A., 2005. Himpunan Sembilan Undang-Undang: Kekuasaan Kehakiman, Mahkamah Agung, Mahkamah Konstitusi, Kejaksaan Republik Indonesia, Kepolisian negara republi Indonesia, Peradilan Umum, Peradilan Hak Azasi Manusia, Komisi Kebenaran dan Rekonsiliasi, Komisi Yudisial. Malang, Universitas Muhammadiyah.

Moeltano, 1997. Azas-azas Hukum Pidana. Jakarta, Bian Aksara.

Mohd. Syaufi Syamsuddin, 2005. Hukum Acara Penyelesaian Perselisihan Hubungan Industrial. Jakarta, Sarana Bhakti Persada.

Muchtar A. Kamaruddin, 2002. Hukum Jaminan Sosial; Menelaah Hakikat dan Pemberdayaan Jaminan Sosial tenaga kerja Harian di Indonesia. Makassar, Umitoha Ukhuwah grafika.

Muzni Tambusai, 2004. Peranan dan Fungsi Mediator, Arbiter dan Konsiliator Menurut UU Nomor 2 Tahun 2004. Jakarta, Direktur jenderal Pembinaan Hubungan Industrial - departemen Tenaga kerja dan Transmigrasi Republik Indonesia.

Poerwadarminta, W J.S., 1996. Kamus Umum Bahasa Indonesia. Jakarta, Balai Pustaka.

Retnowulan Sutantio dan Iskandar Oeripkartawinata, 1996. Hukum Acara Perdata Dalam Teori dan praktek. Bandung, Alumni.

Satjipto Rahardjo, 1996. Ilmu Hukum. Bandung, Alumni.

Soerjono Soekanto, 1993. Tata Cara penyusunan Karya Tulis Ilmiah Bidang Hukum. Jakarta, Ghalia Indonesia.

Subekti, 1983. Hukum Perjanjian. Jakarta, Intermase.

Sudkino Mertokusumo, 1992. Hukum Acara Perdata Indonesia. Yogyakarta, Liberty.

Van Apeldoorn, L.J., 1983. Pengantar Ilmu Hukum. Jakarta, Pradnya paramita.

Wantjik Saleh, K., 1996. Hukum Acara Perdata RBG/HIR. Jakarta, Ghalia Indonesia.

Wiwoho Soedjono, 1997. Hukum Perjanjian Kerja. Jakarta, Bina Aksara. 